\title{
$(S)$-NORLAUDANOSOLINE SYNTHASE: THE FIRST ENZYME IN THE BENZYLISOQUINOLINE BIOSYNTHETIC PATHWAY
}

\author{
Martina RUEFFER, Hannemarie EL-SHAGI, Naotaka NAGAKURA* and Meinhart H. ZENK \\ Lehrstuhl Pharmazeutische Biologie, Universität München, 8000 München 2, FRG and ${ }^{*}$ Kobe Women's College of Pharmacy, \\ 658 Kobe, Japan
}

Received 21 April 1981

\section{Introduction}

Isoquinoline alkaloids form the largest group of alkaloids in the plant kingdom. Numerous publications deal with aspects of the biosynthesis of these compounds in vivo [1], while isoquinoline biosynthesis at the cell-free level had hardly been touched [2]. The initial reaction in isoquinoline biosynthesis has long [3] been assumed to be a condensation of two aromatic units, both derived from tyrosine, namely dopamine and 3,4-dihydroxyphenylacetaldehyde [4]. This scheme was later modified [5] where it was reported that condensation of dopamine with 3,4-dihydroxyphenylpyruvate would lead to an amino acid, norlaudanosoline-1-carboxylic acid, which in turn, by decarboxylation, would yield norlaudanosoline, the well-recognised precursor of papaver-alkaloids $[6,7]$. The intermediary nature of norlaudanosoline-1-carboxylic acid was later claimed to be supported by in vivo $[8]$ and in vitro $[9,10]$ experiments. The stereochemical aspects of this condensation remained, however, unresolved, and there was considerable dispute with regard to an inversion of configuration of the precursors during the biosynthesis of morphine-type alkaloids $[11,12]$. Therefore, a detailed study of this early step in isoquinoline biosynthesis appeared warranted.

Here we report that in cell-free systems from representatives of 10 different genera from 3 plant families containing benzylisoquinoline alkaloids, we were able to detect a novel enzyme which condenses dopamine with 3,4-dihydroxyphenylacetaldehyde to yield directly norlaudanosoline. The aldehyde rather than the postulated 3,4-dihydroxyphenylpyruvate is the substrate for this condensation reaction. The reaction product was proven to posses $\mathrm{L}(-) 1-\alpha-\mathrm{H}-(S)$ - configuration. The enzyme catalysing this reaction was named $(S)$-norlaudanosoline synthase. In contrast to previous assumptions $[5,8-10]$ it appears now that the first natural intermediate in the benzylisoquinoline pathway is $(S)$-norlaudanosoline rather than norlaudanosoline-1-carboxylic acid.

\section{Materials and methods}

\subsection{Norlaudanosoline synthase assay}

The assay is based on the fact that carbonylic substrates reacting with dopamine in a Pictet-Spengler condensation will release ${ }^{3} \mathrm{H}$ from position 6 of the aromatic ring of dopamine into the ambient medium. This was verified by allowing the condensation of $132 \mu \mathrm{mol}$ [ring $-2,6{ }^{3} \mathrm{H}, 2-{ }^{14} \mathrm{C}$ ] dopamine $\left({ }^{3} \mathrm{H}:{ }^{14} \mathrm{C}=\right.$ 3.14:1) with $132 \mu \mathrm{mol} 3,4$-dihydroxyphenylacetaldehyde at $\mathrm{pH} 4.3$. Norlaudanosoline was isolated (25\% yield) and rigorously purified. It showed a ${ }^{3} \mathrm{H}:{ }^{14} \mathrm{C}$ ratio of $1.51: 1$ (theory, 1.57:1) which proves that, indeed, one proton only is removed from this substrate during the condensation.

[ring $-2,6 \mathrm{-}^{3} \mathrm{H}$ ]Dopamine $(3.7 \mathrm{mCi} / \mu \mathrm{mol})$ was synthetized by standard methods using commercially available [ring- $\left.2,6{ }^{3} \mathrm{H}\right]$ tyrosine (Amersham) as starting material and diluted appropiately with unlabelled material. The release of tritium into the medium was used as a measure for cnzymc activity $[13,14]$ taking into account that only one tritium atom of [ring$\left.2,6-{ }^{3} \mathrm{H}\right]$ dopamine is lost during the reaction. Enzyme activity is expressed as the amount of dopamine converted to norlaudanosoline.

Standard assay conditions were as follows: $0.1 \mu \mathrm{mol}$ [ring-2,6. $\left.{ }^{3} \mathrm{H}\right]$ dopamine $85570 \mathrm{dpm}$ incubated with $0.5 \mu \mathrm{mol}$ of the respective second substrate in the 
presence of $20 \mu \mathrm{mol}$ ascorbate, phosphate buffer ( $20 \mu \mathrm{mol} \mathrm{pH} 7.8$ ), enzyme preparation (1 ing protein), and water in $0.25 \mathrm{ml}$ total vol. Incubation was at $30^{\circ} \mathrm{C}$. The reaction was stopped by the addition of $0.3 \mathrm{ml}$ charcoal ( $300 \mathrm{mg}$ ) suspension, agitation of the sample for $1 \mathrm{~min}$, and subsequent centrifugation (9980 rev./min) for $5 \mathrm{~min}$ (Eppendorf System). Aqueous phase $(0.2 \mathrm{ml})$ was transferred to a scintillation vial, mixed with $5 \mathrm{ml}$ Quickscint scintillation fluid (Koch-Light), and counted for radioactivity. A set of controls with either heat-denatured enzyme or without carbonylic substrate was included. The amount of ${ }^{3} \mathrm{H}$ released by the non-enzymatic condensation of the substrates under these conditions was subtracted from the samples containing active enzyme.

\subsection{Plant cell cultures}

Over the last 5 years $\sim 250$ plant species containing isoquinoline alkaloids were grown in tissue culture in this laboratory. Out of these, $\sim 80$ species were selected for subsequent optimization of alkaloid production. The cultures were established and grown in B 5 medium [15] supplemented with $0.5 \mathrm{mg}$ indole acetic acid/1, $0.5 \mathrm{mg}$ naphthalene acetic acid/1, $2 \mathrm{mg}$ 2,4-dichlorophenoxy acetic acid $/ 1$ and $0.2 \mathrm{mg}$ kinetin $/ 1$ (subsequently called $4 \times$ medium). For alkaloid formation, the cells were allowed to grow in the production medium at $23^{\circ} \mathrm{C}$ at $\sim 750$ lux (fluorescent light), and the cells harvested after an 8 day growth period. The tissue was frozen in liquid nitrogen and either used immediately or stored at $-20^{\circ} \mathrm{C}$.

\subsection{Enzyme preparation}

Frozen cells $(30 \mathrm{~g})$ were allowed to thaw in the presence of $60 \mathrm{ml} 0.1 \mathrm{M}$ phosphate buffer ( $\mathrm{pH} 7.0$ ) containing $20 \mathrm{mM} \beta$-mercaptoethanol. The mixture was stirred for $30 \mathrm{~min}$. The slurry was passed through cheesecloth and centrifuged at $48000 \times \mathrm{g}$ for $10 \mathrm{~min}$ at $4^{\circ} \mathrm{C}$. The supernatant was decanted and subjected to $\left(\mathrm{NH}_{2}\right) \mathrm{SO}_{4}$ fractionation. The fractions obtained by saturation with solid $\left(\mathrm{NH}_{4}\right)_{2} \mathrm{SO}_{4}$ at $35-50 \%$ saturation were used in the experiments.

Protein concentrations were determined by the modified Lowry method [16].

\subsection{Chemicals}

3,4-Dihydroxyphenylpyruvate [17] was the kind gift of Professor Steglich, Bonn; all other substrates were prepared by standard procedures or were com- mercially available (Sigma). Compounds were acetylated by incubating the dry material with a large excess of dry pyridine/acetic anhydride $(1: 1)$. Excess anhydride was destroyed by adding water, the pentaacetate extracted with ether, washed with $2 \mathrm{~N} \mathrm{H}_{2} \mathrm{SO}_{4}$ and water, and dried over anhydrous $\mathrm{Na}_{2} \mathrm{SO}_{4}$. The ether was evaporated and the residue subjected to TLC (benzene:acetic acid $=8: 2$; benzene:dioxane:acetic acid $=90: 25: 4$; The $R_{\mathrm{F}}$ values of norlaudanosoline pentaacetate were 0.38 and 0.52 , respectively).

Paper chromatography was performed by using $n$-butanol:acetic acid: $\mathrm{H}_{2} \mathrm{O}=4: 1: 5$ as solvent (norlaudanosoline: $R_{\mathrm{F}}=0.85$ ).

\section{Results}

\subsection{Survey of enzyme activity}

As Schöpf and Bayerle observed in 1934, incubation of dopamine and appropriate aldehydes under so called physiological conditions leads to the nonenzymatic formation of benzylisoquinoline derivatives [18]. This reaction was also observed under our standard conditions and was strictly dependent on the presence of a substrate with a carbonyl function. In the absence of enzyme and in the presence of 3,4-dihydroxyphenylacetaldehyde, tritium was released at $0.01 \mu \mathrm{mol} / 1$. Addition of enzyme from Eschscholtzia tenuifolia $(1 \mathrm{mg})$ drastically enhanced, $(\leqslant 0.035 \mu \mathrm{mol} / \mathrm{h}$ ), the reaction rate. This reaction was dependent on the amount of enzyme added; heat denatured enzyme did not show this effect. Cell cultures of representatives of 10 genera containing isoquinoline alkaloids were selected and tested as above. Furthermore, 2 potential substrates, 3,4-dihydroxyphenylacetaldehyde and 3,4-dihydroxyphenylpyruvate, were employed. As a control, 3 cell cultures derived from plants which contain other alkaloids or no alkaloids at all were also investigated. The results are summarized in table 1. Enzyme activity was detected in all species containing isoquinoline alkaloids. 3,4-Dihydroxyphenylacetaldehyde was by far the best substrate for the condensation reaction with dopamine, while 3,4-dihydroxyphenylpyruvate gave no or only marginal activity. 4-Hydroxyphenylacetaldehyde was also a substrate for the enzyme while both 4-hydroxyphenylpyruvate and phenylpyruvate gave no reaction. The enzyme activity was completely absent from those species which did not contain isoquinoline alkaloids such as Nicotiana, Catharanthus 
Table 1

Survey of distribution of norlaudanosoline synthase activity in species of different genera and families with different carbonylic substrates

\begin{tabular}{|c|c|c|c|}
\hline \multirow[t]{2}{*}{ Plant material } & \multirow[t]{2}{*}{ Family } & \multicolumn{2}{|c|}{$\begin{array}{l}\text { Enzyme activity (pkat/mg protein) } \\
\text { with different substrates }\end{array}$} \\
\hline & & $\begin{array}{l}\text { 3,4-dihydroxy- } \\
\text { phenylacetaldehyde }\end{array}$ & $\begin{array}{l}\text { 3,4-dihydroxy } \\
\text { phenylpyruvate }\end{array}$ \\
\hline Berberis regeliana & Berberidaceae & 5.4 & $<0.1$ \\
\hline Catharanthus roseus & Apocynaceae & 0 & 0 \\
\hline Corydalis sempervireus & Papaveraceae & 4.9 & 0 \\
\hline Daucus carota & Umbelliferae & 0 & 0 \\
\hline Dicentra spectabilis & Papaveraceae & 5,0 & $<0.1$ \\
\hline Eschschoitzia pulchella & Papaveraceae & 16.2 & 0 \\
\hline Fumaria officinalis & Papaveraceae & 1.9 & 0 \\
\hline Glaucium rubrum & Papaveraceae & 3.5 & 0 \\
\hline Meconopsis cambrica & Papaveraceae & 9.9 & 0 \\
\hline Nicotiana sylvestris & Solanaceae & 0 & 0 \\
\hline Papaver somniferum & Papaveraceae & 9.4 & $<0.1$ \\
\hline Ranunculus flammula & Ranunculaceae & 1.0 & 0 \\
\hline Thalictrum tuberosum & Ranunculaceae & 16.0 & 0 \\
\hline
\end{tabular}

or Dattcus proving that this enzyme is present in and specific for plants containing benzylisoquinoline alkaloids. In contrast to $[9,10]$, Triton X-100 treatment had no influence on the enzyme activity, using the aldehyde or pyruvate as substrate.

\subsection{Properties of norlaudanosoline synthase}

\section{2, . Reaction as a function of time, protein and substrate concentration}

The enzyme-catalyzed net release of ${ }^{3} \mathrm{H}$ from the substrate, which corresponds to norlaudanosoline formation, was linear over $\geqslant 40 \mathrm{~min}$. The rate of reaction was linear up to $300 \mu \mathrm{g}$ protein under standard assay conditions. The temperature optimum was found to be $35^{\circ} \mathrm{C}$. The enzyme exhibited normal Michaelis-Menten kinetics with 3,4-dihydroxyphenylacetaldehyde and dopamine. Apparent $K_{\mathrm{m}}$-values were calculated using a computer program for linear regression analysis of a straight line of the MichaelisMenten plot. They were found to be $1 \mathrm{mM}$ for 3,4-dihydroxyphenylacetaldehyde and $5 \mathrm{mM}$ for dopamine for the enzyme from $E$. tenuifolia.

\subsection{2. $\mathrm{pH}$ optimum}

The enzyme activity shows a broad profile ranging from $\mathrm{pH} 5-9$ with a clear optimum around $\mathrm{pH} 7.8$ as shown in fig. 1. Phosphate buffer did not inhibit the reaction.
3.2.3. Nature of the reaction product

$\left[2{ }^{14} \mathrm{C}\right]$ Dopamine $\left(6 \mu \mathrm{mol}, 1.6 \times 10^{6} \mathrm{dpm} / \mu \mathrm{mol}\right)$ were allowed to react with an excess of 3,4-dihydroxyphenylacetaldehyde $(30 \mu \mathrm{mol})$ in $4 \mathrm{mi}$ total vol. phosphate buffer ( $\mathrm{pH} 7.8,800 \mu \mathrm{mol})$ in the presence of $20 \mathrm{mg}$ protein from $E$. tenuifolia. After $2 \mathrm{~h}$ at $30^{\circ} \mathrm{C}$ the mixture was freeze dried. The residue was suspended in methanol and subjected to paper chro-

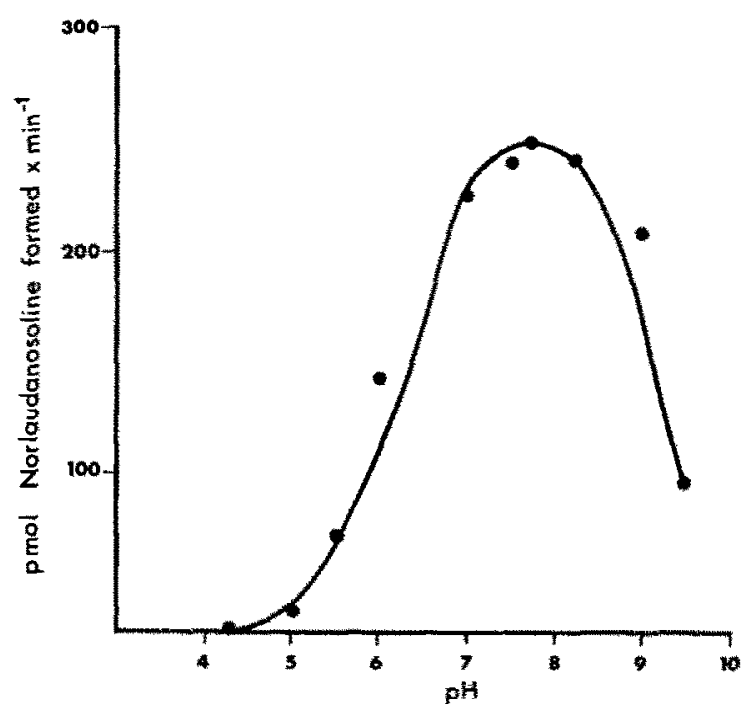

Fig.1. pH profile of the catalytic activity of (\$)-notlaudanosoline synthase from $E$. tenuifolia cell cultures. 
matography. The labelled product $\left(R_{\mathrm{F}} 0.85\right)$ was isolated (yield 10\%) and had spec. act. $1.53 \times 10^{6} \mathrm{dpm} /$ $\mu \mathrm{mol}$. It was acetylated and yielded after several purification steps the pentaacetate with spec. act. $1.51 \mathrm{X}$ $10^{6} \mathrm{dpm} / \mu \mathrm{mol} . \mathrm{MS} m / e 497\left(\mathrm{M}^{+}, 1 \%\right), 291(3 \%)$, $289(51 \%), 247(100 \%), 205(57 \%), 168(49 \%)$ was identical with chemically synthetized norlaudanosoline pentaacetate. The identity of the product was thus established.

\subsubsection{Stereochemistry of the enzymic reaction product}

Large scale incubation of dopamine ( $48 \mu \mathrm{mol})$ with 3,4-dihydroxyphenylacetaldehyde $(240 \mu \mathrm{mol})$ in the presence of $9.6 \mathrm{mmol}$ phosphate buffer (pH 7.8), ascorbate and $650 \mathrm{mg}$ protein from E. tenuifolia in $120 \mathrm{ml}$ total vol. yielded norlaudanosoline which was processed as above. The pentaacetate was subjected to circular dichroism (CD) measurement and showed the following characteristics: $\max 274 \mathrm{~nm}(\Delta e+0.13)$; $220 \mathrm{~nm}(-0.4) ; 205 \mathrm{~nm}(+1.2)$. Comparison with the CD spectra of authentic $(+)$ and $(-)$ norlaudanosoline pentaacetates of known absolute configuration derived from $(+)$ and $(-)$ tetrahydropapaverines [19] showed beyond doubt that $20-25 \%$ of the recovered material was optically pure and had the $1-\alpha-\mathrm{H}-(S)$-configuration. The $(S)$-enantiomer was predominantly formed also by the enzyme from Thalictrum minus and Meconopsis cambrica. The low yield of the optical pure compound can be explained in two ways: either normally occurring chemical condensation of $\sim 50 \%$, which yields the racemate, is increased in large scale batches or a small amount $(\sim 10 \%)$ of $(R)$-norlaudanosoline is formed besides the excess of the $(S)$-enantiomer thus yielding $\sim 25 \%$ enzymatically formed $(R, S)$-mixture adding up with the chemically formed racemate to $\sim 75 \%$ of $(R, S)$ mixture. This problem will be further investigated. Since, however, all 3 enzyme-preparations from different plants gave about the same yield of optically pure material, the first explanation given here is at present favoured.

The possible occurrence of a norlaudanosoline racemase was tested by incubating pure $(S)$ - or $(R)$ norlaudanosoline with enzymes from $E$. tenuifolia under identical conditions as above and carrying the pure enantiomers through the entire isolation, acetylation and purification procedure. No evidence for racemisation was found. The enantiomers were recovered in absolutely pure optical form.

\section{Conclusion}

A novel enzyme (S)-norlaudanosoline synthase, catalysing the condensation of dopamine with 3,4-dihydroxyphenylacetaldehyde by a Pictet-Spengler type reaction, was discovered and proven to be of common occurrence in several members of plants containing isoquinolines. In the assay, the enzyme catalyses the reaction shown in fig. 2 . Use was made of the fact that during the condensation reaction the hydrogen atom at $\mathrm{C}-6$ of the aromatic ring of dopamine is removed. Using $\left[\right.$ ring- $\left.2,6-{ }^{3} \mathrm{H}\right]$ dopamine, the enzymatically-catalysed elimination of tritium makes a convenient and sensitive quantitative test for this enzyme. The lost tritium atom can be measured in the ambient aqueous solution. The enzyme is specific for the aldehyde substrate and yields a product with 1- $\alpha$-H-(S)-configuration. 3,4-Dihydroxyphenylacetaldehyde and to a lesser extent, 4-hydroxyphenylacetaldehyde and phenylacetaldehyde serve as substrates. 3,4-Dihydroxyphenylpyruvate, 4-hydroxyphenylpyruvate and phenylpyruvate were not utilized. Thus, the old hypothesis of Winterstein and Trier [4] is realized in nature, in that dopamine condenses with a substituted phenylacetaldehyde to yield simple
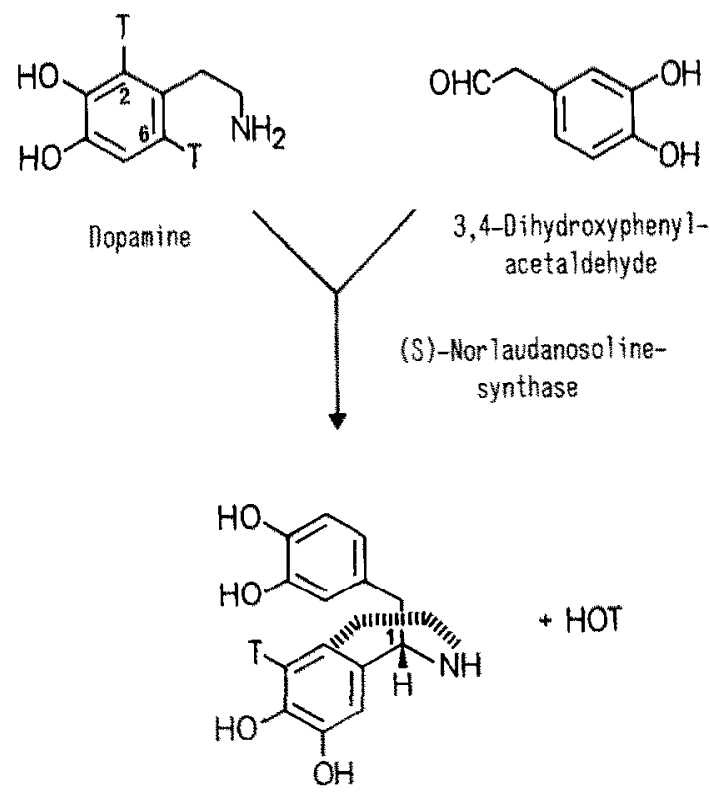

1a-(S)-Nor laudanosoline

Fig.2. Scheme of reaction catalysed by (S)-norlaudanosoline synthase indicating also the assay principle. 
isoquinoline alkaloids. The enzyme was purified $\sim 40$-fold and shown to be absolutely specific for the phenylacetaldehydes. This substrate specificity rules out the long discussed possibility $[5,8-10,20]$ that position 1 of benzylisoquinoline alkaloids and any substituent thereon are biogenetically derived from the appropriate keto acid via a Pictet-Spengler ring closure reaction. The observed metabolization of chemically synthetized norlaudanosoline-1-carboxylic acid, which we now believe to be an unnatural compound, to different alkaloids in vivo $[5,8,21]$ may be due to the fact that this amino acid easily undergoes oxidative decarboxylation either in air under slightly basic conditions $[5,22]$ or by enzymes which occur widely in plant cells, such as peroxidases or laccases [23]. The observation that labelled dopa and dopamine were incorporated into norlaudanosoline-1carboxylic acid in papaver plants in vivo or in papaver latex [5] may be due to the easiness of chemical condensation of dopamine with 3,4-dihydroxyphenylpyruvate which both exist in the plant. Dopa is known to be transaminated in plants. Unfortunately, the stereochemistry of the isolated norlaudanosoline1 -carboxylic acid was not determined in these studies $[5,9,10]$ so that the question cannot yet be answered whether this amino acid is an artifact or not. Since the papaver cell cultures used here produced neither thebaine nor morphine or codeine, there remains the slight possibility that a specific pathway leading to papaver alkaloids via norlaudanosoline-1-carboxylic acid exists in these plants which is repressed under our culture conditions [24]. Nevertheless, on the basis of the results presented here we can firmly conclude that the major pathway to the structurally diverse benzylisoquinoline alkaloids involves $(S)$-norlaudanosoline as the first and central intermediate.

\section{Acknowledgements}

We are grateful to Mrs W. Conrad for technical assistance, to Professor G. Snatzke, Bochum, for measuring and interpreting the $\mathrm{CD}$ spectra, and to the Minister für Forschung and Technologie, Bonn, for financial support.

\section{References}

[1] Shamma, M. (1972) The Isoquinoline Alkaloids Academic Press, London, New York.

[2] Shamma, M. and Moniot, J. L. (1978) Isoquinoline Alkaloids Research 1972-1977, Plenum, London, New York.

[3] Spenser, I. D. (1968) in: Comprehensive Biochemistry, vol. 20, (Florkin, M. and Stotz, E. H. eds) Elsevier/ North Holland, Amsterdam, New York.

[4] Winterstein, E. and Trier, G. (1910) in: Die Alkaloide, p. 307, Gebrüder Bornträger, Berlin.

[5] Wilson, M. L. and Coscia ${ }_{7}$. J. (1975) J. Am, Chem. Soc. 97,431 .

[6] Battersby, A. R. and Binks, R. (1960) Proc. Chem. Soc. 360.

[7] Battersby, A. R., Binks, R., Francis, R. J.; McCaldin, D. J. and Ramuz, H. (1964) J. Chem. Soc. 3600.

[8] Battersby, A. R., Jones, R. C. F. and Kazlauskas, R. (1975) Tetrahedron Lett. 1873.

[9] Scott, A. I., Lee, S.-L., Hirata, T. and Culver, M. G. (1978) Rev, Latinoamer. Quim. 9, 131.

[10] Scott, A. I., Lee, S.-L. and Hirata, T. (1978) Heterocycles 11,159

[11] Battersby, A. R., Foulkes, D. M. and Binks, R. (1965) J. Chem. Soc. 3323.

[12] Brochmann-Hanssen, E., Chen, C.-H., Chen, C. R., Chiang, H.C., Leung, A. Y, and McMurtey, K. (1975) J. Chem. Soc. 1531, Perkin I.

[13] Treimer, J. F, and Zenk, M. H. (1979) FEBS Lett. 97, 159.

[14] Treimer, J. F, and Zenk, M. H. (1979) Eur. J Biochem. 101,225 .

[15] Gamborg, O. L., Miller, R. A. and Ojima, K. (1968) Exp. Cell Res. 50, 151 .

[16] Bensadoun, A, and Weinstein, D. (1976) Anal. Biochem. 70, 241 .

[17] Weygand, F., Steglich, W. and Tanner, H. (1962) Liebigs Ann, Chem. $658,128$.

[18] Schöpf, C. and Bayerle, H. (1934) Liebigs Ann. Chem. 513,190 .

[19] Corrodi, H. and Hardegger, E. (1956) Helv. Chim. Acta 39,889 .

[20] Hahn, G. and Rumpf, F. (1938) Berichte Chem. Ges. $71,2141$.

[21] Bhakuni, D. S., Singh, A. N., Tewari, S. and Kapil, R. S. (1977) J, Chem. Soc. 1662, Perkin I.

[22] Bobbitt, J. M., Kulkarni, C. L. and Wirivachita, P. (1976) Heterocycles 4,1645 .

[23] Coutts, I. G. C., Hamblin, M. R. and Tinley, E. I. and Bobbitt, I. M. (1979) J. Chem. Soc. 2744, Perkin I.

[24] Furuya, T. Nakano, M. and Yoshikawa, T. (1978) Phytochemistry 17,891 . 